\title{
Use of transcutaneous electrical acupoint stimulation for prevention of postoperative delirium in geriatric patients with silent lacunar infarction
}

This article was published in the following Dove Medical Press journal:

Clinical Interventions in Aging

\author{
Hai-Jun Hou \\ Fu-Shan Xue \\ Rui-Juan Guo \\ Department of Anesthesiology, Beijing \\ Friendship Hospital, Capital Medical \\ University, Beijing, People's Republic \\ of China
}

\section{Dear editor}

In a preliminary study, Gao et $\mathrm{al}^{1}$ assessed the preventive effect of transcutaneous electrical acupoint stimulation (TEAS) on postoperative delirium (POD) in geriatric patients with silent lacunar infarction. They showed that TEAS could reduce the development of POD and might be related to attenuated neuroinflammation by reducing the permeability of the blood-brain barrier. Given that POD is a common postoperative complication associated with adverse events and outcomes including functional decline, and increased risks of morbidity and mortality in elderly surgical patients, their findings have the potential implications. To differentiate the real effect of one factor on primary endpoint in a randomized trial, however, all of other factors must be standardized for avoidance of potential bias. Other than the limitations described in the discussion, we noted several issues in this study that were not addressed well.

First, study subjects were elderly patients undergoing spine surgery. The study did not provide the baseline education level and preoperative serum albumin concentration of patients. In available literature, both lower baseline education level and preoperative albumin concentration have been identified as significant risk factor of POD in elderly surgical patients. ${ }^{2,3}$ Regarding intraoperative factors, moreover, only providing anesthesia and operation durations were insufficient. It has been shown that intraoperative major blood loss and blood transfusion are significantly associated with an increased risk of POD after noncardiac surgery in elderly patients. ${ }^{4}$ In addition, the authors did not observe and compare the incidences of postoperative adverse events and complications between groups. In fact, prolonged hospital and intensive care unit stay, postoperative complications including urinary tract infection, pneumonia, and cognitive impairment can increase the risk of POD after noncardiac surgery. ${ }^{5} \mathrm{We}$ are concerned that any imbalance in the above unknown factors would have biased their findings.

Second, this study excluded patients with an increased risk of POD, such as those with mini-mental state examination score of $<24$ or dementia, preoperative delirium, history of neurological or mental illness, current use of tranquilizers or antidepressants. ${ }^{5}$ Thus, an important question that remains unanswered in this study is whether TEAS is an effective treatment in elderly patients with an increased risk of POD. Furthermore, this study only assessed the incidence of POD, but not the severity and duration of POD due to a short observed time. The available evidence indicates that both more severe POD and longer in-hospital POD duration are significantly associated with
Correspondence: Fu-Shan Xue

Department of Anesthesiology, Beijing Friendship Hospital, Capital Medical University, No 95 Yong-An Road, Xi-Cheng District, Beijing I00050, People's Republic of China Tel +86 I39 III 7655

Fax +861063138362

Email xuefushan@aliyun.com 
worse postoperative outcomes. ${ }^{6}$ We believe that the results of this study would be more informative if the design had included these issues.

Finally, because of the small sample size, small intergroup mean differences and large standard deviations in this study, we questioned their results that serum levels of TNF- $\alpha$ and IL-6 were higher at $\mathrm{T}_{2-3}$ and serum levels of MMP-9 and $\mathrm{S} 100 \beta$ were higher at $\mathrm{T}_{3}$ in group $\mathrm{C}$ compared with group TEAS $(P<0.05)$. Revalidation of these results with statistical software confirms our doubts.

\section{Acknowledgment}

All authors report no financial support.

\section{Disclosure}

The authors report no conflicts of interest in this communication.

\section{References}

1. Gao F, Zhang Q, Li Y, et al. Transcutaneous electrical acupoint stimulation for prevention of postoperative delirium in geriatric patients with silent lacunar infarction: a preliminary study. Clin Interv Aging. 2018;13:2127-2134.

2. Sprung J, Roberts RO, Weingarten TN, et al. Postoperative delirium in elderly patients is associated with subsequent cognitive impairment. Br J Anaesth. 2017;119(2):316-323.

3. Patti R, Saitta M, Cusumano G, Termine G, Di Vita G. Risk factors for postoperative delirium after colorectal surgery for carcinoma. Eur $J$ Oncol Nurs. 2011;15(5):519-523.

4. Marcantonio ER, Goldman L, Orav EJ, Cook EF, Lee TH. The association of intraoperative factors with the development of postoperative delirium. Am J Med. 1998;105:380-384.

5. Smith TO, Cooper A, Peryer G, Griffiths R, Fox C, Cross J. Factors predicting incidence of post-operative delirium in older people following hip fracture surgery: a systematic review and meta-analysis. Int J Geriatr Psychiatry. 2017;32(4):386-396.

6. Hughes CG, Patel MB, Jackson JC, et al.; MIND-ICU, BRAIN-ICU Investigators. Surgery and anesthesia exposure is not a risk factor for cognitive impairment after major noncardiac surgery and critical illness. Ann Surg. 2017;265(6):1126-1133. 


\section{Authors' reply}

Fang Gao,' Qi Zhang, ${ }^{2}$ Yanan Li,' Yanlei Tai,' Xi Xin, ${ }^{3}$ Xiuli Wang,' Qiujun Wang'

'Department of Anesthesiology, The Third Hospital of Hebei Medical University, Shijiazhuang City, Hebei, People's Republic of China; ${ }^{2}$ Department of Anesthesiology, Children's Hospital of Hebei Province, Shijiazhuang City, Hebei, People's Republic of China; ${ }^{3}$ Department of Anesthesiology, Tianjin Third Central Hospital, Tianjin, People's Republic of China

Correspondence: Qiujun Wang

Department of Anesthesiology, The Third Hospital of Hebei Medical University, No 139, Ziqiang Road, Shijiazhuang City, Hebei, People's

Republic of China

$\mathrm{Tel} / \mathrm{fax}+8631$ I 88602072

Email1393317800I@I63.com

\section{Dear editor}

We thank Hou et al for their interest in our paper entitled "Transcutaneous electrical acupoint stimulation for prevention of postoperative delirium in geriatric patients with silent lacunar infarction: a preliminary study" and their valuable comments. Here we respond to their concerns.
Hou et al found that baseline education level, intraoperative major blood loss and blood transfusion, and postoperative complications were identified as significant risk factors of postoperative delirium (POD) in elderly surgical patients in the literature. However, some other previous studies have had conflicting results that these factors were not related to POD. ${ }^{1-3}$ Further studies are needed to confirm these imparities.

For avoidance of potential bias, we set strict exclusion criteria. We would be pleased if our study provokes interest in further research into whether transcutaneous electrical acupoint stimulation (TEAS) is an effective treatment in elderly patients with an increased risk of POD. It will be useful to take into consideration the severity and duration of POD, but unfortunately we did not collect data on these variables due to the short observation time, and we have stated this in the discussion.

Our data were analyzed by SPSS, and the results are as follows.

\begin{tabular}{|c|c|c|c|c|c|c|c|c|c|}
\hline & \multicolumn{2}{|c|}{$\begin{array}{l}\text { Levene's test } \\
\text { for equality of } \\
\text { variances }\end{array}$} & \multicolumn{7}{|c|}{$t$-test for equality of means } \\
\hline & \multirow[t]{2}{*}{$\boldsymbol{F}$} & \multirow[t]{2}{*}{ Sig. } & \multirow[t]{2}{*}{$t$} & \multirow[t]{2}{*}{$d f$} & \multirow[t]{2}{*}{$\begin{array}{l}\text { Sig. } \\
\text { (2-tailed) }\end{array}$} & \multirow[t]{2}{*}{$\begin{array}{l}\text { Mean } \\
\text { difference }\end{array}$} & \multirow[t]{2}{*}{$\begin{array}{l}\text { Std. error } \\
\text { difference }\end{array}$} & \multicolumn{2}{|c|}{$\begin{array}{l}95 \% \text { confidence interval } \\
\text { of the difference }\end{array}$} \\
\hline & & & & & & & & Lower & Upper \\
\hline \multicolumn{10}{|l|}{ MMP93 } \\
\hline $\begin{array}{l}\text { Equal variances } \\
\text { assumed }\end{array}$ & .069 & .793 & -2.084 & 62 & .041 & -.34469 & .16536 & -.67525 & -.01413 \\
\hline $\begin{array}{l}\text { Equal variances not } \\
\text { assumed }\end{array}$ & & & -2.084 & 61.225 & .041 & -.34469 & .16536 & -.67533 & -.01405 \\
\hline \multicolumn{10}{|l|}{ SI00ß3 } \\
\hline $\begin{array}{l}\text { Equal variances } \\
\text { assumed }\end{array}$ & .033 & .857 & -2.177 & 62 & .033 & -6.96437 & 3.19911 & -13.35930 & -.56945 \\
\hline $\begin{array}{l}\text { Equal variances not } \\
\text { assumed }\end{array}$ & & & -2.177 & 61.860 & .033 & -6.96437 & 3.19911 & -13.35959 & -.56916 \\
\hline \multicolumn{10}{|l|}{ TNF2 } \\
\hline $\begin{array}{l}\text { Equal variances } \\
\text { assumed }\end{array}$ & .217 & .643 & -2.606 & 62 & .011 & -3.66750 & 1.40735 & -6.48075 & -.85425 \\
\hline $\begin{array}{l}\text { Equal variances not } \\
\text { assumed }\end{array}$ & & & -2.606 & 61.986 & .011 & -3.66750 & $\mathrm{I} .40735$ & -6.48076 & -.85424 \\
\hline \multicolumn{10}{|l|}{ TNF3 } \\
\hline $\begin{array}{l}\text { Equal variances } \\
\text { assumed }\end{array}$ & .078 & .781 & -2.954 & 62 & .004 & -4.95875 & 1.67863 & $-8.3 \mid 428$ & -1.60322 \\
\hline $\begin{array}{l}\text { Equal variances not } \\
\text { assumed }\end{array}$ & & & -2.954 & 61.270 & .004 & -4.95875 & 1.67863 & $-8.3 \mid 507$ & -1.60243 \\
\hline
\end{tabular}

(Continued) 


\begin{tabular}{|c|c|c|c|c|c|c|c|c|c|}
\hline & \multicolumn{2}{|c|}{$\begin{array}{l}\text { Levene's test } \\
\text { for equality of } \\
\text { variances }\end{array}$} & \multicolumn{7}{|c|}{$t$-test for equality of means } \\
\hline & \multirow[t]{2}{*}{$\boldsymbol{F}$} & \multirow[t]{2}{*}{ Sig. } & \multirow[t]{2}{*}{$t$} & \multirow[t]{2}{*}{$d f$} & \multirow[t]{2}{*}{$\begin{array}{l}\text { Sig. } \\
\text { (2-tailed) }\end{array}$} & \multirow[t]{2}{*}{$\begin{array}{l}\text { Mean } \\
\text { difference }\end{array}$} & \multirow[t]{2}{*}{$\begin{array}{l}\text { Std. error } \\
\text { difference }\end{array}$} & \multicolumn{2}{|c|}{$\begin{array}{l}95 \% \text { confidence interval } \\
\text { of the difference }\end{array}$} \\
\hline & & & & & & & & Lower & Upper \\
\hline \multicolumn{10}{|l|}{ IL62 } \\
\hline $\begin{array}{l}\text { Equal variances } \\
\text { assumed }\end{array}$ & .024 & .877 & -2.617 & 62 & .011 & -4.27750 & 1.63449 & $-7.5448 \mathrm{I}$ & -1.01019 \\
\hline $\begin{array}{l}\text { Equal variances not } \\
\text { assumed }\end{array}$ & & & -2.617 & 61.998 & .011 & -4.27750 & 1.63449 & -7.54481 & -1.01019 \\
\hline \multicolumn{10}{|l|}{ IL63 } \\
\hline $\begin{array}{l}\text { Equal variances } \\
\text { assumed }\end{array}$ & .736 & .394 & -2.073 & 62 & .042 & -3.32375 & 1.60304 & -6.52819 & -.11931 \\
\hline $\begin{array}{l}\text { Equal variances not } \\
\text { assumed }\end{array}$ & & & -2.073 & 61.566 & .042 & -3.32375 & 1.60304 & -6.52864 & -.11886 \\
\hline
\end{tabular}

Abbreviations: MMP93, the concentration of matrix metallo proteinase- 9 at $T_{3}$; s10033, the concentration of sI00 33 at $T_{3}$; TNF2, the concentration of tumor necrosis factor- $\alpha$ at $T_{2}$; TNF3, the concentration of tumor necrosis factor- $\alpha$ at $T_{3}$; IL62, the concentration of interleukin-6 at $T_{2}$; IL63, the concentration of interleukin-6 at $T_{3}$.

\section{Disclosure}

The authors report no conflicts of interest in this communication.

\section{References}

1. Kobayashi K, Imagama S, Ando K, et al. Risk Factors for delirium after spine surgery in extremely elderly patients aged 80 years or older and review of the literature: Japan Association of Spine Surgeons with Ambition Multicenter Study. Global Spine J. 2017;7(6):560-566.
2. Brown CH 4th, LaFlam A, Max L, et al. Delirium after spine surgery in older adults: incidence, risk factors, and outcomes. $J$ Am Geriatr Soc. 2016;64(10):2101-2108.

3. Jiang X, Chen D, Lou Y, et al. Risk factors for postoperative delirium after spine surgery in middle- and old-aged patients. Aging Clin Exp Res. 2017;29(5):1039-1044.

Dove Medical Press encourages responsible, free and frank academic debate. The content of the Clinical Interventions in Aging 'letters to the editor' section does not necessarily represent the views of Dove Medical Press, its officers, agents, employees, related entities or the Clinical Interventions in Aging editors. While all reasonable steps have been taken to confirm the content of each letter, Dove Medical Press accepts no liability in respect of the content of any letter, nor is it responsible for the content and accuracy of any letter to the editor.

Clinical Interventions in Aging

\section{Publish your work in this journal}

Clinical Interventions in Aging is an international, peer-reviewed journal focusing on evidence-based reports on the value or lack thereof of treatments intended to prevent or delay the onset of maladaptive correlates of aging in human beings. This journal is indexed on PubMed Central, MedLine,
CAS, Scopus and the Elsevier Bibliographic databases. The manuscript management system is completely online and includes a very quick and fair peer-review system, which is all easy to use. Visit http://www.dovepress. com/testimonials.php to read real quotes from published authors. 